\title{
MAKALAH \\ PEMBAGIAN DAN PERKEMBANGAN ANTROPOLOGI HUKUM
}

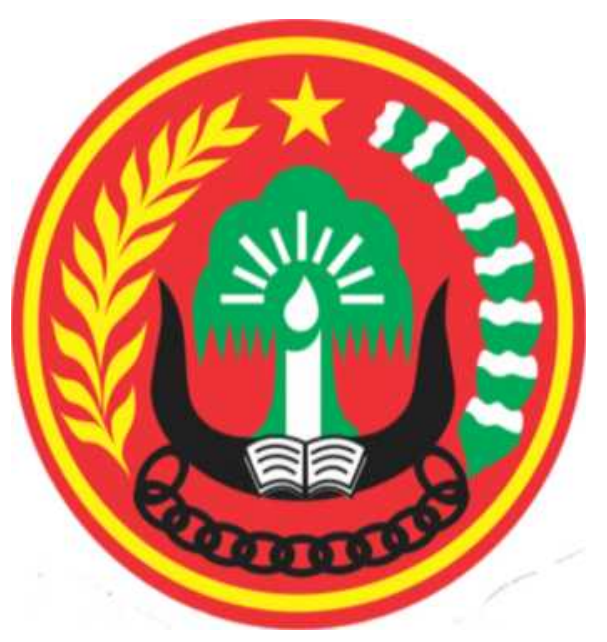

Disusun oleh:

$\begin{array}{ll}\text { Nama Mahasiswa } & \text { :Muhammad Yusuf } \\ \text { Email } & : m y u s u f 8 s u k m a @ g m a i l . c o m \\ \text { No BP } & : 2110003600169 \\ \text { Perguruan Tinggi } & : \text { Universitas Ekasakti } \\ & \text { Ilmu Hukum }\end{array}$




\section{BAB 1}

\section{PENDAHULUAN}

\section{A. LATAR BELAKANG}

Antropologi secara etimologis berasal dari bahasa Yunani. Kata anthroposberartimanusia dan logosberarti ilmu pengetahuan. Jadi antropologi adalah ilmu yang mempelajarimanusia. Dalam ilmu antropologi hukum dipelajari mengenai peran, status atau kedudukan,nilai, norma juga kebudayaan. Semua ini sangat erat kaitannya dengan ilmu antropologihukum. Sebelum berdirinya Komunisme, magistrat-magistrat Tiongkok, misalnya, tidakberurusan dengan menginterpretasi dan menerapkan aturan hukum untuk kasus-kasus konflikyang terjadi, namun menggunakan aturan hukum hanya sebagai pedoman teladan-teladanyang sangat berguna, tetapi tidak harus diteladani dalam kasus konkrit. Dalam antropologihukum tidak dapat membatasi diri pada isi peraturan-peraturan hukum dan bentuk- bentuksanksinya, tapi yang perlu diketahui dengan jelas adalah proses pembentukan hukumnya.Antropologi hukum adalah ilmu yang mempelajari tentang manusia dan budayanyakhusus dihidang hukum. Kebudayaan hukum yang dimaksud adalah kekuasaan yangdigunakan oleh penguasa untuk mengatur masyarakat agar tidak melanggar kaidah-kaidahsosial yang telah ada didalam suatu masyarakat itu sendiri.Hukum dipahami sebagai milik sebuah masyarakat sebagai suatu keseluruhan.Konsekuensi logisnya, suatu masyarakat dianggap hanya memiliki satu sistem hukum sajayang mengendalikan perilaku semua anggotanya. Tanpa sedikit pun menyelidiki kontrol-kontrol sosial yang bekerja pada tingkat submasyarakat, subkelompok (misalnya,perkumpulan, kelompok orang yang hidup serumah, dan kelompok kerabat) telah secara apriori dikecualikan dari kemungkinan mengatur perilaku anggotanya dengan sistem yangditerapkan oleh pemimpin kelompok dalam keputusan-keputusan khusus sistem yangberdasarkan ciri-ciri khas esensinya amat sangat menyerupai hukum pada masyarakat yangmeliputi semua kalangan.Hukum juga diartikan sebagai disiplin (sistem ajaran tentang kenyataan) dan ilmupengetahuan (yakni ilmu hukum). Sebagai ilmu pengetahuan, maka hukum dikatakanmencangkup ilmu tentang kaidah, ilmu tentang pengertian dasar sistem hukum dan ilmukenyataan (seperti misalnya sosiologi hukum, antropologi hukum, psikologi hukum,perbandingan hukum dan sejarah hukum) Pengertian lain tentang hukum yaitu bahwa hukum diartikan sebagai prosespemerintahan. Proses pemerintahan itu mencangkup peraturan, pemerintahan dalam artisempit, penanggulangan serta peradilan. Hukum diartikan pula sebagai jalinan nilai. Nilai tersebut merupakan konsepsi abstrak di dalam diri manusia mengenai apa yang dianggap baikserta apa yang dianggap buruk. Hukum diartikan sebagai nilai yang merupakan salah satuunsur pandangan manusia mengenai hal-hal yang seharusnya dianuti karena dianggap baik,dan hal-hal yang seharusnya dihindari karena dianggap buruk. 


\section{BAB 2 \\ PEMBAHASAN}

\subsection{Pengertian antapologi hukum}

Antropologi hukum adalah kajian antropologis terhadap makna sosial dari dan pentingnya hukum dengan menelaah bagaimana hukum dibuat termasuk bagaimana konteks sosial pembuatan hukum tersebut, bagaimana hukum mempertahankan dan mengubah institusi sosial lainnya, dan bagaimana hukum membangun perilaku sosial.] Namun seiring perkembangan zaman dan tatanan politik dunia pasca-Perang Dingin, cakupan kajian antropologi hukum meluas di antaranya membahas keterkaitan antara konflik sosial dengan kesenjangan ekonomi dan batasan-batasan hukum dalam melakukan rekayasa sosial. Antropologi hukum kini turut mengkaji hubungan antara politik dan hukum yang juga berubah dalam konteks pasca-Perang Dingin tersebut. Sebagai akibat dari perluasan cakupan tersebut, bahkan ada kalangan yang menyebut kajian antropologi hukum pada abad ke-19 sebagai kajian antropologi protolega

Pengertian lain tentang hukum yaitu bahwa hukum diartikan sebagai prosespemerintahan. Proses pemerintahan itu mencangkup peraturan, pemerintahan dalam arti sempit, penanggulangan serta peradilan. Hukum diartikan pula sebagai jalinan nilai. Nilai tersebut merupakan konsepsi abstrak di dalam diri manusia mengenai apa yang dianggap baikserta apa yang dianggap buruk. Hukum diartikan sebagai nilai yang merupakan salah satuunsur pandangan manusia mengenai hal-hal yang seharusnya dianuti karena dianggap baik,dan hal-hal yang seharusnya dihindari karena dianggap buruk

\subsection{Pembagian Antropologi hukum}

Antropologi mempelajari perkembangan kehidupan manusia dan budayanya, dengan cabang-cabang ilmu, diantaranya; ilmu PraSejarah untuk mempelajari kehidupan asal usul manusia, dan untuk mengetahui ragam bahasa manusia maka harus mempelajari Etnolinguistik, sedangkan ilmu yang mempelajari cara manusia berbangsa dan berbudaya disebut Etnologi.

Antropologi adalah studi ilmu yang mempelajari tentang manusia dari Aspek Budaya, Perilaku, Nilai, Keanekaragaman, dan lainnya.

Antropologi terbagi dalam: Antropologi Ekonomi, Antropologi Politik, Antropologi Pendidikan, dan Antropologi Hukum.

Antropologi Hukum merupakan ilmu yg mempelajari manusia dengan kebudayaan, khususnya di bidang Hukum, atau ilmu tentang Manusia dalam kaitannya dengan Kaidah-kaidah sosial yang bersifat Hukum.

\subsection{Hubungan Budaya Dan Kebudayaan Hukum}

Hukum sangat berkaitan erat dengan kebudayaan. Hukum sendiri merupakan produk kebudayaan, karena sejatinya produk hukum adalah produk ciptaan manusia. Dalam studi hukum dikenal struktur hukum, substansi hukum, dan budaya hukum. Hukum diciptakan memiliki karakteristik yang berbeda-beda dari satu daerah ke daerah lainnya sesuai dengan kebudayaan setempat. Artinya, kebudayaan membentuk hukum. Menurut Prof. Tjip, hukum itu bukanlah skema yang final[3], tetapi terus bergerak sesuai dengan dinamika dan perkembangan zaman umat manusia. Artinya, hukum akan terus berubah sesuai dengan perkembangan zaman dan dinamika manusia ini terlahir dalam proses kebudayaan yang berbeda. 
Kebudayaan yang terdapat dalam masyarakat terlibat dalam hal pembentukan hukum. Di Indonesia dikenal adanya masyarakat Hukum Adat yang jumlahnya sangat banyak. Perkembangan kebudayaan dan hukum menciptakan suatu subjek hukum yang bernama Hukum Adat. Dalam Pendidikan Tinggi hukum, terdapat mata kuliah yang kaitannya dengan Hukum, Masyarakat, dan Kebudayaan: Hukum Adat, Antropologi Hukum, Hukum dan Masyarakat, dan Sosiologi Hukum. Mata kuliah- mata kuliah inilah adalah awal pengenalan mahasiswa hukum terhadap hubungan dari hukum dan kebudayaan.

Bahwa kebudayaan memiliki peran penting terhadap eksistensi hukum. Dimensi kebudayaan ini masuk kedalam norma-norma hukum. Hal ini teijadi dengan adanya Hukum Adat yang lebih sempit lagi melahirkan konsep-konsep hak tanah atas masyarakat adat yang lebih sering dikenal sebagai hak ulayat. Kebudayaan juga memberi ruang dalam proses penyelesaian perkara secara informal, seperti yang teijadi dalam masyarakat Kpelle di Liberia Tengah, Afrika. Kebudayaan hadir dimana-dimana, dan membentuk sebuah pemahaman hukum yang sifatnya pluralis

\subsection{Arena kajian Antropologi hukum}

Kajian Antropologi Hukum adalah menggali norma dan nilai-nilai dalam masyarakat.

Arena Antropologi Hukum mempelajari manusia dan budaya hukum, karenanya kaidah sosial yang tidak bersifat hukum bukanlah sasaran pokok penelitian Antropologi Hukum.

Norma / kaidah menurut Antropologi Hukum pola ulangan perilaku dalam masyarakat. Norma / Kaidah adalah nilai dasar yang ada dalam masyarakat yang dapat mengukur perilaku manusia agar dapat menilai mana perbuatan benar dan mana yang tidak benar. Norma memiliki aspek hukum ketika aparat menjatuhkan sanksi karena ada perbuatan yang menyimpang atau melanggar hukum.

Sanksi bersifat positif seperti dengan membayar denda atau keija sosial, dan sanksi bersifat negatif seperti hukuman badan atau dikucilkan..

Hukum muncul dari peradaban manusia, dimana ada 2 orang atau lebih di situ ada hukum.

\subsection{Sifat keilmuan antropologi hukum}

1. Antropologi Hukum tidak membatasi pandangan pada kebudayaan tertentu (studi perbandingan).

2. Antroplogi Hukum, mempelajari masyarakat sebagai suatu keseluruhan yang utuh, dimana bagian-bagiannya saling bertautan.

3. Antropologi Hukum Modern tidak memusatkan perhatian hanya pada kekuatan sosial dan hal superorganis.

4. Antropologi Hukum memandang masyarakat secara Dinamis, sehingga peranan sosial dan Hukum tidak terbatas mempertahankan status quo.

5. Antropologi Hukum termasuk ilmu Hukum yang empiris.

\subsection{Ruang Lingkup Antropologi Hukum}

Ruang Lingkup Antropologi Hukum adalah suatu spesialisasi dari Antropologi Budaya, Antropologi Sosial, dan Kebudayaan Hukum yang menyangkut Aspek - aspek Hukum.

Laura Nader dalam bukunya "The Anthropological Study of Law " ( 1965 ), mengemukakan masalah pokok yang merupakan ruang lingkup Antropologi Hukum sebagai berikut:

1. Apakah dalam setiap masyarakat terdapat Hukum dan bagaimana karateristik Hukum yg Universal? 
2. Bagaimana Hubungan antara Hukum dengan aspek kebudayaan dan organisasi sosial?

3. Apakah mungkin diadakan Tipologi Hukum tertentu sedangkan variasi karakteristik hukum terbatas?

4. Apakah Tipologi Hukum berguna untuk menelaah hubungan antara Hukum dengan Aspek Budaya dan organisasi sosial, dan

5. Mengapa Hukum itu berubah, setrta bagaimana cara mendeskripsikan Sistem- sistem Hukum?

\section{7 kajian antropologi hukum dengan ilmu sosial lainya}

Di dalam perkembangan antropologi, masalah hukum sebenarnya juga sudah pernah ditelaah, walaupun di dalam suatu kerangka kebudayaan yang serba luas. Saijana-saijana antropologi seperti Barton, Radcliffe-Brown, Malinowski dan lainnya, pernah memusatkan perhatian pada hukum sebagai suatu gejala sosial-budaya. Menurut Ihromi (1986; 3) relevansi

menelaah hukum dari segi antropologi, antara lain adalah: (a). Berkenaan dengan masalah yang dihadapi oleh negara-negara berkembang (tentunya termasuk Indonesia) yang secara budaya bersifat pluralistis dalam cita-citanya mewujudkan unifikasi hukum atau modernisasi hokum; (b), berkenaan dengan kemungkinan munculnya masalah bila warga masyarakat dari lingkungan sukubangsa tertentu masih mempunyai norma-norma tradisional yang kuat dan menuntut ketaatan mengenai hal-hal tertentu, sedangkan dalam norma hukum yang sudah tertulis dan berlaku secara nasional, hal- hal yang harus ditaati itu justru dirumuskan sebagai hal yang terlarang.

Secara faktual, masalah-masalah yang dirumuskan ke dalam dua point utama itu sudah teijadi, baik berkenaan dengan munculnya konflik horisontal di pelbagai wilayah, pertikaian antara state (maupun pemda) dengan masyarakat, maupun antar kelompok masyarakat sendiri. Hukum, menurut Benda-Beckmann (1979; 113-114) adalah suatu cara khusus untuk membatasi otonomi anggota-anggota masyarakat. Kebanyakan penulis menyetujui bahwa hukum adalah suatu bentuk pengawasan sosial, itulah mengapa secara esensial sifatnya normatif, dan hal itu merujuk pada apa yang disebut (sebagai) konsepsikonsepsi yang obyektif.

Implikasi pendekatan semacam ini adalah: bahwa hukum memberi input kepada pranata pengendalian sosial (apapun variant-nya) dan kemudian kepada rujukan berpikir masyarakat, dan sebaliknya. Hukum, di sisi lain, dapat pula menyebabkan perubahan perangkat berpikir, dan rujukan kemasyarakatan lainnya atau dikenal dalam sosiologi hukum sebagai "law as tool of social engineering".

Namun, bila kesemua hal itu berubah (dan pada kenyataannya memang selalu demikian), maka hukum pun berubah mengikuti perubahan masyarakat danlingkungannya.

bidang ilmu lainnya, seperti dengan ilmu administrasi, Ilmu Politik, Ilmu Sejarah, dan sebagainya.

\subsection{Sejarah Antropologi Hukum}

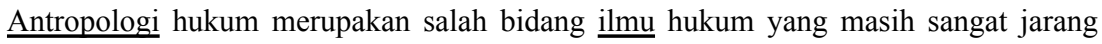


diketahui oleh masyarakat luas. Orang lebih mengenal antropologi sebagai bidang ilmu yang dekat dengan peristiwa sejarah dan budaya dan karena itu tidak mungkin memiliki kaitan dengan ilmu hukum. Namun inilah hukum, bidang ilmu yang sangat luas dan mencakup hampir seluruh aspek kehidupan manusia.

Awal 1970-an dapat dicatat sebagai formulasi dari perkembangan pendidikan ilmu hukum empiris dengan menggunakan pendekatan sosiologis untuk mengkaji fenomenafenomena hukum dalam masyarakat sedang berkembang di Indonesia, yang dikenal kemudian sebagai disiplin sosiologihukum (sociology of law). Nama-nama akademisi hukum seperti Soeijono Soekanto (alm.) dari UI, Satjipto Rahardjo dari UNDIP, dan Sutandyo Wignyosubroto dari UNAIR dapat dicatat sebagai para perintis pengenalan mata kuliah sosiologi hukum di fakultas-fakultas hukum di Jawa.

Kemudian, sejak warsa 1980-an dunia pendidikan ilmu hukum di Indonesia semakin diperkaya dengan pengenalan studi-studi hukum empiris dengan menggunakan pendekatan antropologis. Untuk ini, T.O. Ihromi dan Valerine J.L. Kriekhoff dari UI bekeijasama dengan F. von Benda-Beckmann dari Wageningen Agriculture University the Netherlands dapat dinobatkan sebagai peletak dasar studi- studi antropologis tentang hukum yang kemudian dikenal sebagai antropologihukum (anthropology of law,legal anthropology, anthropological study of law). Makalah bersahaja ini mencoba untuk memberi pemahaman mengenai antropologi hukum sebagai bidang studi ilmu hukum empiris, dengan berfokus pada awal pemikiran studi-studi antropologis tentang hukum, pengembangan konsep hukum dalam studi antropologi hukum, perkembangan tematema kajian antropologi hukum, metodologi antropologi hukum, dan diskusi tema kemajemukan hukum dalam studi antropologi hukum.

Dari optik ilmu hukum, antropologi hukum pada dasarnya adalah sub disiplin ilmu hukum empiris yang memusatkan perhatiannya pada studi-studi hukum dengan menggunakan pendekatan antropologis. Kendati demikian, dari sudut pandang antropologi, sub disiplin antropologi budaya yang memfokuskan kajiannya pada fenomena empiris kehidupan hukum dalam masyarakatsecara luas dikenal sebagai antropologi hukum.[3] Antropologi hukum pada dasarnya mempelajari hubungan timbalbalik antara hukum dengan fenomena-fenomena sosial secara empiris dalam kehidupan masyarakat; bagaimana hukum berfungsi dalam kehidupan masyarakat, atau bagaimana hukum bekeija sebagai alat pengendalian sosial (social control) atau sarana untuk menjaga keteraturan sosial (social order) dalam masyarakat. Dengan kata lain, studi-studi antropologis mengenai hukum memberi perhatianpada segi-segi kebudayaan manusia yang berkaitan dengan fenomena hukum dalam fungsinya sebagai sarana menjaga keteraturan sosial atau alat pengendalian sosial (Pospisil, 1971 :x, 1973:538; Ihromi, 1989:8). Karena itu, studi antropologis mengenai hukum secara khusus mempelajari prosesproses sosial di mana pengaturan mengenai hak dan kewajiban warga masyarakat diciptakan, dirobah, dimanipulasi, diinterpretasi, dan diimplementasikan oleh warga masyarakat (F. von Benda-Beckmann, 1979, 1986).

Awal pemikiran antropologis tentang hukum dimulai dengan studi-studi yang dilakukan oleh kalangan ahli antropologi dan bukan dari kalangan saijana hukum. Awal kelahiran antropologi hukum biasanya dikaitkan dengan karya klasik Sir Henry Maine yang bertajuk The Ancient Law yang diterbitkan pertama kali pada tahun 1861. Ia dipandang sebagai peletak dasar studi antropologis tentang hukum melalui introduksi teori evolusionistik (the evolusionistic theory) mengenai masyarakat dan hukum, yang secara ringkas menyatakan: hukum berkembang seiring dan sejalan dengan perkembangan masyarakat, dari masyarakat yang sederhana (primitive), tradisional, dan kesukuan (tribal) ke masyarakat yang kompleks dan modern, dan hukum yang inherent dengan masyarakat semula menekankan pada status 
kemudian wujudnya berkembang ke bentuk kontrak (Nader, 1965; Roberts, 1979; Krygier, 1980; Snyder, 1981).

Tema kajian pada fase awal studi-studi teoritis mengenai hukum dengan pendekatan antropologis lebih difokuskan pada fenomena hukum dalam masyarakat bersahaja (primitive), tradisional (traditional), dan kesukuan (tribal) dalam skala evolusi bentuk-bentuk organisasi sosial dan hukum yang mengiringi perkembangan masyarakat manusia. Sedangkan, metode kajian yang digunakan untuk memahami fenomena hukum dalam masyarakat adalah apa yang dikenal sebagai armchair methodology, yaitu metodologi untuk memahami hukum dalam perkembangan masyarakat melalui kajian-kajian yang dilakukan di belakang meja, sambil duduk di kursi empuk, dalam ruangan yang nyaman, dengan membaca dan menganalisis sebanyak mungkin documentary data yang bersumber dari catatan- catatan peijalanan para petualang atau pelancong, dari laporan-laporan berkala dan dokumen resmi para missionaris, pegawai sipil maupun para serdadu pemerintah kolonial dari daerah-daerah jajahannya (F. von BendaBeckmann, 1989).

Pada awal abad ke-20 metode kajian hukum dari belakang meja mulai ditinggalkan, dan mulai memasuki perkembangan metode studi lapangan (fieldwork methodology) dalam studi-studi antropologis tentang hukum. Karya Barton, misalnya, yang beijudul Ifugao Law yang dipublikasikan pertama kali pada tahun 1919 merupakan hasil dari field work yang intensif dalam masyarakat suku Ifugao di Pulau Luzon Philipina. Kemudian, muncul karya Malinowski beijudul Crime and Custom in Savage Society yang pertama kali dipublikasikan pada tahun 1926 adalah hasil studi lapangan yang komprehensif dalam masyarakat suku Trobrian di kawasan Lautan Pasific, dan seterusnya sampai sekarang metode field work menjadi metode khas dalam studi-studi antropologi hukum.

Tema-tema kajian yang dominan pada fase awal perkembangan antropologi hukum berkisar pada pertanyaan-pertanyaan : apakah hukum itu ? apakah ada hukum dalam masyarakat yang bersahaja, tradisional, dan

kesukuan ?; bagaimanakah hukum berujud dan beroperasi dalam kehidupan masyarakat ? Pada dekade tahun 1940-an sampai 1950-an tema-tema kajian antropologi hukum mulai bergeser ke mekanisme-mekanisme penyelesaian sengketa dalam masyarakat sederhana. Karya klasik dari Llewellyn dan Hoebel bertajuk The Cheyenne Way (1941) merupakan hasil studi lapangan kolaborasi dari seorang saijana hukum dengan ahli antropologi dalam masyarakat suku Cheyenne (suku Indian) di Amerika Serikat.

Kemudian, Hoebel mempublikasikan The Law of Primitive Man (1954), disusul dengan karya Gluckman mengenai hukum orang Barotse dan Lozi di Afrika, karya Bohannan mengenai hukum orang Tiv, karya Gulliver mengenai hukum orang Arusha dan Ndendeuli. Karya Fallers mengenai hukum dalam masyarakat suku Soga, dan karya Pospisil tentang hukum orang Kapauku di Papua. Fase perkembangan tema studi antropologi hukum ke arah mekanisme-mekanisme peneyelesaian sengketa seperti disebutkan di atas disebut oleh F. von Benda-Beckmann (1989) sebagai fase the anthropology of dispute settlements. Pada dekade tahun 1960-an tema studi-studi antropologi lebih memberi perhatian pada fenomena kemajemukan hukum atau pluralisme hukum. Tema pluralisme hukum pertama-tama difokuskan pada kemajemukan cara-cara penyelesaian melalui mekanisme tradisional, tetapi kemudian diarahkan kepada mekanisme dan institusi penyelesaian sengketa menurut hukum pemerintahkolonial dan pemerintah negara-negara yang sudah merdeka. Karya 
Bohannan, Gluckman, dan Gulliver misalnya, tidak secara sistematis memberi perhatian pada eksistensi mekanisme dan institusi penyelesaian sengketa menurut hukum kolonial dan hukum negara-negara sedang berkembang.

Sejak tahun 1970-an tema studi-studi antropologi hukum secara sistematis difokuskan pada hubungan antar institusi-institusi penyelesaian sengketa secara tradisional, neo-tradisional, dan menurut institusi hukum negara. Karya Nader dan Todd (1978) misalnya, memfokuskan kajiannya pada proses, mekanisme, dan institusi-institusi penyelesaian sengketa di komunitas masyarakattradisional dan modern di beberapa negara di dunia, melalui Berkeley Village Law Projects, menjadi karya yang memperlihatkan kecenderungan baru dari topik-topik studi antropologi hukum. Publikasi lain yang perlu dicatat adalah mekanisme penyelesaian sengketa di kalangan orang Togo di Afrika karya van Rouveroy van Nieuwaal, kemudian karya F. von BendaBeckmann (1979) dan K. von Benda-Beckmann (1984) yang memberi pemahaman tentang penyelesaian sengketa harta warisan di kalangan orang Minangkabau menurut pengadilan adat dan di pengadilan negeri di Sumatera Barat.

Fase selanjutnya studi pluralisme mekanisme penyelesaian sengketa mulai ditinggalkan, dan mulai diarahkan kepada studi-studi pluralisme hukum di luar penyelesaian sengketa. Karya Sally F. Moore (1978) misalnya, mengenai kemajemukan hukum agraris dalam kehidupan suku Kilimanjaro di Afrika, dan mekanisme dalam proses produksi pabrik garment terkenal di Amerika dapat dicatat sebagai perkembangan baru studi pluralisme hukum. Kemudian, studi-studi pluralisme hukum mulai difokuskan pada mekanisme jaminan sosial (social security), pasar dan perdagangan, mekanisme irigasi pertanian, institusi koperasi dan perkreditan di daerah pedesaan di negara-negara sedang berkembang. Studi-studi ini dikembangkan oleh AgrarianLawDepartmentWageningenAgricultureUniversity. Fase perkembangan tema pluralisme hukum yang menyoroti topik-topik penyelesaian sengketa maupun non penyelesaian sengketa, interaksi antara hukum negara, hukum

rakyat, atau dengan hukum agama disebut oleh F. von Benda-Beckmann (1989) sebagai fase the anthropology of legal pluralism. Kecenderungan yang berkembang sejak tahun 1970-an adalah penggunaan pendekatan sejarah dalam studi- studi antropologi hukum. Studi yang dilakukan Moore (1986), Snyder (1981), F. von Benda-Beckmann (1979), K. von Benda-Beckmann (1984) misalnya, secara eksplisit menggunakan kombinasi dimensi sejarah untuk menjelaskan interaksi institusi hukum negara (state law) dengan hukum rakyat (folk law) dalam kajian pluralisme hukum penyelesaian sengketa. 
2.9. Perbedaan Antropologi Hukum, Sosiologi Hukum dan Hukum Adat

\begin{tabular}{|c|c|}
\hline ANTROPOLOGI HUKUM & SOSIOLOGI HUKUM \\
\hline $\begin{array}{l}\text { 1. Antropologi hukum kajian utamanya } \\
\text { adalah masyarakat pra modem, bersahaja, } \\
\text { primitif. }\end{array}$ & $\begin{array}{l}\text { Sosiologi Hukum kajiannya } \\
\text { adalah pada masyarakat yang } \\
\text { modern dan yang sudah } \\
\text { knmniek }\end{array}$ \\
\hline $\begin{array}{l}\text { 2. Perbedaan lahir dari ilmu: } \\
\text { lahir dari sebuah proses ketertarikan oran } \\
\text { Eropa Barat menjelajah duniakhususnya } \\
\text { mempelajari orang Asia, Afrika, kegiatan } \\
\text { ini dimulai oleh } \\
\text { Colombus.(menemukan }\end{array}$ & $\begin{array}{l}\text { lahir untuk } \\
\text { menyelesaikan } \\
\text { pemecahan persoalan,lahir } \\
\text { dari revolusi di prancis. }\end{array}$ \\
\hline $\begin{array}{l}\text { 3. Konsekuensi Metologi: } \\
\text { Pendekatan Metologinya adalah deskriptif } \\
\text { analitik (yang menjelaskan yang }\end{array}$ & $\begin{array}{l}\text { Yang bersifat evaluatif (yang } \\
\text { bersifat kuantitatif) }\end{array}$ \\
\hline $\begin{array}{l}\text { 1. Dalam Menganalisis data-data } \\
\text { yang } \\
\text { sudah terungkap: } \\
\text { Menggunakan Analisis Induksi (Khusus- } \\
\text { umum).induksi adalah persepsi sikap dan }\end{array}$ & $\begin{array}{l}\text { Analisis } \\
\text { m- } \\
\text { Khusus) }\end{array}$ \\
\hline
\end{tabular}

Perbedaan Antropologi Hukum dengan Hukum Adat

\begin{tabular}{|c|l|l|l|}
\hline No & \multicolumn{1}{|c|}{ Item } & Antroplogi Hukum & \multicolumn{1}{|c|}{ Hukum Adat } \\
\hline 1 & Obyek & Perilaku manusia & $\begin{array}{l}\text { Norma hukum di luar } \\
\text { UU }\end{array}$ \\
\hline 2 & Pendekatan & Holistik & Yuridis normatif \\
\hline 3 & Sifat Penelitian & Penelitian lapangan & $\begin{array}{l}\text { Studi pustaka \& } \\
\text { dokumen }\end{array}$ \\
\hline 4 & Norma & Kenyataan & Dikehendaki \\
\hline
\end{tabular}

Aliran Antropologi Hukum

1. Aliran Evolusionisme.

Asumsi Dasar Kebudayaan mengalami proses perubahan dari satu tahap ketahap selanjutnya secara evoluti fTokoh:

a) E.B. Taylor : menemukan teori animisme.

b) J.J. Bachofen : menemukan teori pembentukan keluarga 
c) J.G. Frazer : menemukan teori batas akal atau magi

d) R.R. Maret: menemukan teori dinamisme

e) Andrew Lang: menemukan teori dewa tertinggi

Kebudayaan dlm Perspektif EvolusionismeKebudayaan dalam perspektif Antropologi Evolusionisme terbagi dalam tiga konsepsi:

a) Kebudayaan sebagai sebuah sistem(cultural system)

Yaitu berupa gagasan, pikiran, konsep, nilai, norma, pandangan, undang-undang. Kesemuanya dimiliki oleh pemangku ide dan bersifat abstrak.

b) Kebudayaan sebagai sistem sosial,

Menurut C. Kluckholn kebudayaan sebagai sistem sosial terdiri dari :

1. Sistem peralatan dan perlengkapan hidup

2. Sistem mata pencarian

3. Sistem kemasyarakatan

4. Bahasa

5. Kesenian

6. Sistem pengetahuan

7. Sistem religi

Ketujuh isi kebudayaan itu disebut juga sebagai Unsur-unsur Kebudayaan atau Culturan Universal

c) Kebudayaan sebagai hasil tingkah laku manusia (material culture) Terbagi menjadi 2

1. Benda (Artifak) atau Material Culture

2. Tingkah laku manusia itu sendiri

Desain penelitian perspektif Evolusionisme Cara pandangEvolusionisme

Mendeskripsikan unsur-unsur budaya universal dan pola perubahan yg teramati melalui mekanisme pembandingan kebudayaan yg hidup dan berkembang dalam sebuah 
entitas budaya

\section{Aliran Antropologi Kognitif}

Asumsi dasar Memandang kebudayaan sebagai kognisi manusia atau Melihat kaitan antara bahasa, kebudayaan dan kognisi manusia

Tokoh: Ward H. Goodenough(ahli linguistik yang tertarik pada kebudayaan)

\section{Kajian Antropologi Kognitif}

Bagaimana manusia memandang benda, kejadian dan makna dari dunianya sendiri. Goodenough memandang bahwa kebudayaan bukanlah fenomenamaterial (benda, perilaku, emosi), namun lebih menjadi bagaimana cara pengaturan hal-hal tersebut.

\section{Aliran Antropologi Struktural}

Asumsi dasar : Nalar manusia (human mind) dan sistem relasi (system of relation)

Tokoh : Claude Levi-Strauss

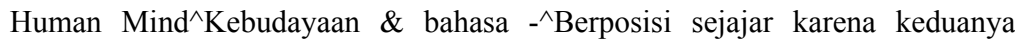
merupakan hasil dari nalar manusia

Antropologi Levi-Strauss bertujuan menemukan model bahasa \& budaya melalui strukturnya Pemahaman thd pikiran \& perilaku kehidupan manusia Sistem Relasi dalam antropologi struktural terbagi dalam 3 bagian yaitu Relasi manusia dengan kebudayaan, Relasi Manusia dengan Bahasa dan relasi manusia dengan Tradisi. Kebudayaan Produk atau hasil aktifitas nalar manusia yang memiliki kesejajaran dengan bahasa \& tradisi. Tradisi Sebuah jalan bagi masyarakat untuk memformulasikan dan memperlakukan fakta-fakta dasar dari eksistensi kehidupan

manusia. Tradisi adalah tatanantransendental sbg pengabsah tindakan \& juga sesuatu yg imanen dlm situasi aktual dan bersesuaian dengan konteks ${ }^{\wedge}$ bersifatdi namis (J.C. Hastermann)

\section{Aliran Antropologi Simbolik - Interpretatif}

Kebudayaan^ ${ }^{\wedge}$ Adalah keseluruhan pengetahuan manusia yang dijadikan sebagai pedoman atau penginterpretasi keseluruhan tindakan manusia. Kebudayaan adalah pedoman bagi masyarakat yang diyakini kebenarannya oleh masyarakat tersebut.

\subsection{Tingkat Kebudayaan}

Kebudayaan dimiliki oleh setiap masyarakat. Perbedaanya terletak pada kesempurnaan kebudayaan itu sendiri.Dari tingkatan kebudayaan dikenal adanya 
super-culture yang berlangsung bagi seluruh masyarakat. Suatu super-culture biasanya dapat dijabarkan ke dalam cultures yg mungkin di dasarkan pd kekhususan daerah, gol etnik, profesi, dst.Dalam culture mungkin berkembang lagi ke dalam kebudayaan khusus yang tidak bertentangan dengan kebudayaan " induk" yang lazimnya dinamakan sub-culture.Namun jika kebudayan khusus tadi bertentangan dengan kebudyaan induk disebut counter culture.

\subsection{Pluralisme Hukum}

Pluralisme hukum secara umum didefinisikan sebagai situasi dimana terdapat dua atau lebih sistem hukum yang berada dalam suatu kehidupan sosial. Pluralisme hukum harus diakui sebagai sebuah realitas masyarakat.

\subsection{Pluralisme Hukum di Indonesia}

pluralitas sendiri merupakan ciri khas Indonesia. Dengan banyak pulau, suku, bahasa, dan budaya, Indonesia ingin membangun bangsa yang stabil dan modem dengan ikatan nasional yang kuat. Sehingga, menurutnya menghindari pluralisme sama saja dengan menghindari kenyataan yang berbeda mengenai cara pandang dan keyakinan yang hidup di masyarkat Indonesia.

Menurut Prof. Erman, kondisi pluralisme hukum yang ada di Indonesia menyebabkan banyak permasalahan ketika hukum dalam kelompok masyarakat diterapkan dalam transaksi tertentu atau saat teijadi konflik, sehingga ada kebingungan hukum yang manakah yang berlaku untuk individu tertentu dan bagaimana seseorang dapat menentukan hukum mana yang berlaku padanya.

\subsection{Pluralisme Hukum Negara}

pluralisme hukum yang lemah ketika negaramengakui kehadiran anasir sistem hukum lain di luar hukum negara, tetapi sistem- sistem hukum non negara tersebut tunduk keberlakuannya di bawah hukum negara.

\subsection{Deep Legal Pluralism}

Sementara itu, jenis pluralisme hukum yang kedua adalah deep legal pluralism, yaitu ketika terdapat tatanan norma di luar hukum negara yang berlaku di masyarakat. Menurut Kamus Besar Bahasa Indonesia (KBBI), norma adalah aturan atau ketentuan yang mengikat warga kelompok dalam masyarakat.

\subsection{Subjek Sengketa Antropologi Hukum}

Masyarakat hukum adat menurut peraturan perundang-undangan secara tegasmengakui keberadaannya. Berdasarkan Pasal 18B ayat (2) Undang-Undang Dasar Tahun 1945, yaitu: Negara mengakui dan menghormati kesatuan-kesatuan masyarakat hukum adat serta hak- hak tradisionalnya sepanjang masih hidup dan sesuai dengan perkembangan masyarakat dan prinsip Negara Kesatuan Republik Indonesia, yang diatur dalam undang- undang.Hukum adat adalah hukum yang bersumber pada ugeran-ugeran atau norma-norma kehidupan sehari-hari yang langsung timbul sebagai pernyataan kebudayaan orang Indonesia asli dalam hal ini sebagai pernyataan rasa keadilan dalam hubungan pamrih, sehingga jelas sekali terlihat bahwa hukum adat adalah hukum asli 
bangsa Indonesia yang dibuat oleh masyarakat Indonesia sendiri secara turun menurun, berdasarkan value counciousness mereka yang termanifestasi dalam kebiasaan-kebiasaan hidup sehari-hari dengan menggunakan

ukuran nalar dan rasa keadilan mereka.6Sistem peradilan orang sumatra berbeda dengan orang Eropa. Mengikuti sistem peradilan orang sumatra, kedua belah pihak yang bertikai jarang memberikan pertanyaan-pertanyaan . bahkan saksipun tidak harus mengucapkan sumpah sebelumnya. Bila suatu fakta dijabarkan, baik dari pihak pendakwa maupun terdakwa,keabsahan peristiwa lah yang dipertanyakan.

\subsection{Proses Sengketa Antropologi Hukum}

Pengkajian Antropologi Hukum telah memberikan telaah akan hasil kreasi, distribusi dan transmisi hukum yang ada. Kajian mengenai bagaimana kekuasaan hukum berproses dan memberi dampak dalam masing-masing masyarakat. Selanjutnya akan menampilkan bagaimana feed back dan pengaruh masyarakat-masyarakat terhadap kekuasaan hukum tersebut. Kemajemukan hukum yang ada di Indonesia dewasa ini merupakan soal tersendiri mengingat otetisitas Antropologi Hukum yang sejak lama menempatkan dan menghargai the other laws secara proporsional dan kontekstual. Dengan demikian para pengkaji antropologi hukum ditantang untuk memberikan kontribusi bagi perkembangan hukum di Indonesia, khususnya terkait dengan korelasi positif the other laws dengan state laws. Dalam perspektif antropologi hukum, hukum lahir dari kebudayaan. Melihat hal tersebut di atas tentunya menyadarkan kepada kita akan peran Antropologi Hukum sebagai sebuah perspektif untuk melihat berbagai macam corak hukum yang lahir dan berkembang pula dari berbagai corak dan ragam kebudayaan. Mempelajari Antropologi Hukum berarti kita melihat sebuah realitas, kenyataan atas kehidupan hukum yang sesungguhnya beijalan di masyarakat.

Satu hal yang dapat kita ambil dari antropologi hukum, adalah diharapkan dapat memunculkan kesadaran atas kenyataan adanya keberagaman hukum karena beragamnya budaya. Beragamnya hukum tersebut jangan dimaknakan sebagai pertentangan hukum (conflict of laws), tetapi patut dianggap sebagai khazanah kekayaan hukum yang akan mampu memperkuat serta memperbaharui hukum nasional. Di sisi lain akibatnya adalah memunculkan sikap toleransi untuk menghargai umat manusia yang beragam pola fikir, karakter, pemahaman, dan tentunya juga beragam hukum.

\subsection{Sengketa Berkepanj angan dalam Pandangan Antropologi Hukum}

Model antropologi hukum yaitu holistik dengan latar belakang budaya hukum dari masyarakat setempat. Ini memberikan gambaran bahwa hukum tidak hanya dilihat pada persoalan perundangan (normatif) atau hukum adat melainkan ada peran budaya. Peran tersebut dapat dilihat dari cara menyelesaikan masalah dengan nilai budaya yang telah 
tertanam. Hukum tidak bisa melihat nilai budaya tersebut tanpa mempelajari antropologi hukum sebab pendekatan dari penyelesaian masalah ini memerlukan pemahaman latar belakang budaya setempat. Sengketa merupakan permasalahan peradilan yang harus diselesaikan. Menurut R Subekti dan R Tjitrosedibio, peradilan yaitu segala sesuatu yang berkaitan dengan tugas negara untuk menegakkan hukum dan keadilan. Umumnya seseorang mendapat keadilan melalui pengadilan, yang mendapat naungan dari Mahkamah Agung. Ini telah diatur dalam Undang-Undang Republik Indonesia Nomor 2 Tahun 1986 tentang Peradilan Umum bahwa pengadilan adalah salah satu pelaksana kekuasaan kehakiman $b$ ari rakyat yang mencari keadilan tetapi itu juga harus mewujudkan kepastian hukum sebagai nilai yang terkandung dalam peraturan hukum (PDP PPZ, 2016). Realitanya, banyak persoalan sengketa yang tidak terdaftar dalam pengadilan, itupun diatasi dengan budaya hukum. Budaya tersebut diselidiki melalui model antropologi hukum. Menurut Nader dan Todd, model tersebut membagi tiga tahap proses sengketa yaitu tahap prakonflik, tahap konflik dan tahap sengketa. Budaya hukum juga memiliki prinsip yaitu ide, sikap, kepercayaan, harapan, dan pandangan tentang hukum. Disinilah, Nader dan Todd membagi tujuh cara penyelesaian sengketa yaitu lumping it (membiarkan saja), avoidance (mengelak), coercion (paksaan), negotiation (perundingan), mediation, arbitration, dan adjudication (peradilan)

\subsection{Model Penyelesaian Sengketa dalam Pandangan Antropologi Hukum}

1. Dalam kehidupan sosial sebagian besar masyarakat Indonesia cenderung untuk menghindari teijadinya sengketa dengan siapa pun, karena nilai-nilai pergaulan sosial yang dianut lebih bersifat personal, komunal, mengutamakan solidaritas, dan bernuansa magis. Karena itu, apabila teijadi sengketa maka cenderung diselesaikan melalui prosedur kompromi, konsiliasi, mengutamakan pendekatan personal dan kekerabatan .

2. Sengketa antar individu sedapat mungkin dihindari, dan kalau pun harus teijadi maka sengketa cenderung ditutupi dengan gaya hubungan sosial yang halus, untuk memperoleh penyelesaian yang tidak sampai merusak hubungan dan pergaulan sosial, 
apalagi menjatuhkan martabat atau merendahkan derajat pihak yang diajak bersengketa.

3. Fokus penyelesaian sengketa bukan pada penerapan peraturan hukum yang digunakan, tetapi lebih pada upaya pelenyapan sengketa yang menjadi sumber ketegangan sosial.

\subsection{Pendekatan Holistik dalam Antropologi Hukum}

Holistik berarti menyeluruh. Yang diartikan dari pendekatan ini adalah meneliti suatu masalah social budaya dalam rangka kehidupan masyarakat secara menyeluruh. Metode ini dikembangkan dalam fasenya untuk masyarakat pedesaan (rural) kecil yang dapat dicakup seluruhnya

Pendekatan Holistik berarti bahwa semua faktor diperhitungkan secara keseluruhan, saling bergantung satu sama lain untuk kepentingan semua

Pendekatan yang digunakan Antropologi Hukum dalam mengkaji hukum adalah menggunakan pendekatan Holistik (menyeluruh) terhadap seluruh aspek kehidupan manusia antara lain hukum, ekonomi, politik, termasuk budaya. Antropologi hukum itu tidak membatasi pandangannya pada kebudayaan tertentu.

\subsection{Pendekatan Empirik dalam Antropologi Hukum}

Empiris (empirical). Artinya, bahwa Antropologi Hukum merupakan suatu disiplin yang didasarkan atas:

(a) observasi terhadap kenyataan (social fact),

(b) penggunaan akal sehat (true logic), dan

(c) hasilnya tidak spekulatif (data based).

\subsection{Pendekatan Komparatif dalam Antropologi Hukum}

Pendekatan komparatif merupakan pendekatan yang merujuk pada pola perbandingan dengan meletakkan dua hal budaya pada sisi yang sama dan juga menjelaskan sisi-sisi yang berbeda.

\subsection{Melihat Gejala Sosial yang ada Dimasyarakat}

Kemiskinan

Kemiskinan merupakan suatu kondisi ketika individu atau sebuah kelompok gak sanggup untuk memenuhi kebutuhan hidup sehari-hari dan sulit mengakses pelayanan yang dibutuhkan. Bentuk sekaligus faktor penyebab kemiskinan itu ada tiga, yaitu: 
Natural. Kemiskinan ini disebabkan oleh faktor-faktor yang alami. Misalnya, karena individu tersebut cacat atau sakit, sehingga ia kesulitan memenuhi kebutuhannya dan termasuk kategori miskin.

Kultural. Jenis kemiskinan ini berbahaya, nih, Pahamifren. Kemiskinan kultural ini disebabkan karena individu tersebut sudah merasa cukup sama hidupnya. Jadi dia males-malesan dan gak disiplin, gak ada usaha untuk membuat hidupnya jadi lebih baik. Dari sinilah seseorang bisa mengalami kemiskinan.

Struktural. Individu atau suatu kelompok bisa jadi miskin karena sesuatu yang dibuat oleh manusia. Misalnya, kebijakan yang gak adil, distribusi barang ataupun makanan yang gak merata, dan korupsi

\section{Kriminalitas}

Jenis masalah sosial uang kedua adalah kriminalitas. Kamu masih inget gak kalau kriminalitas merupakan salah satu bentuk dari penyimpangan sosial? Soalnya para pelaku kriminal ini berperilaku gak sesuai dengan norma dan nilai yang dianut masyarakat dan melanggar hukum yang berlaku. Kriminalitas biasanya identik dengan pencopetan, pembunuhan, atau penggunaan narkoba yang dilakukan oleh masyarakat menengah ke bawah. Tapi jangan salah, ya, kriminalitas juga dilakukan oleh masyarakat menengah ke atas, loh. Contohnya adalah korupsi, koruptor menyalahgunakan kekuasaan dan uang rakyat untuk kepentingan pribadi atau kelompok mereka sendiri, sehingga membuat kelompok lain jadi kesulitan. Inilah yang dikenal sebagai white collar crime.

Kesenjangan Sosial dan Ketidakadilan

Kesenjangan sosial merupakan salah satu akibat dari adanya stratifikasi sosial, yang membeda-bedakan masyarakat. Dalam hal ini, masyarakat kelas atas biasanya lebih mudah mendapatkan segala sesuatu, sedangkan kelas bawah kesulitan mendapatkan akses pelayanan ataupun memenuhi kebutuhan hidupnya. Nah, terakhir ada ketidakadilan. Ketidakadilan adalah suatu kondisi saat suatu kelompok atau individu diperlakukan berbeda dan dipinggirkan di masyarakat. Salah satu contoh ketidakadilan adalah isu yang sempat ramai di Amerika, "BlackLives Matter". Padahal semestinya semua orang diperlakukan dengan cara yang sama, ya, Pahamifren.

\subsection{Pendekatan Holistik Melalui Tindakan Stereotip}

(prejudice) muncul dari komunitas mayoritas terhadap komunitas minoritas bagaimana stereotip Definisi atas konsep stereotip mengikuti pengertian yang dikemukakan oleh ... Pemilihan perhatian, pendekatan, konsep formasi dan dan juga memberi justifikasi tindakan seseorang terhadap kelompok sosial lain.

\subsection{Teori Evolusionisme (Antropologi Hukum)}

Evolusi kebudayaan bisa didefinisikan sebagai suatu perubahan atau perkembangan kebudayaan, seperti perubahan dari bentuk sederhana menjadi kompleks (Syaifudin, 2005 : 99 ). Perubahan itu biasanya bersifat lambat laun, paradigma yang berkaitan dengan konsep evolusi tersebut adalah evolusionalisme yang berarti cara pandang yang menekankan perubahan lambat laun menjadi lebih baik atau lebih maju 
dan dari sederhana ke kompleks. Teori evolusi menggambarkan bahwa perubahan kebudayaan teijadi secara perlahan-lahan dan bertahap. Setiap masyarakat mengalami proses evolusi yang berbeda - beda. Oleh karena itu, masing - masing masyarakat menunjukkan kebudayaan yang berbeda - beda. Salah satu masyarakat dikenal telah maju, sedangkan masyarakat yang lain masih dianggap atau tergolong sebagai masyarakat yang belum maju.

Adalah teori tertua dan dikembangkan oleh 2 tokoh pertama dalam antropologi, ialah Edward Bumet Tylor (1832-1917) dan Lewis henry Morgan (1818-1889). Teori ini berangkat dari anggapan bahwa ada suatu hukum (aturan) universal yang mengendalikan perkembangan semua kebudayaan manusia. Menurut teori ini setiap kebudayaan mengalami evolusi melalui jalur dan fase-fase yang sudah pasti

\subsection{Teori Fungsionalisme (Antropologi Hukum)}

Teori ini dikembangkan oleh Bronislaw Malinowski (1884-1942) yang selama Perang Dunia II mengisolir diri bersama penduduk asli pulau Trobrian untuk mempelajari cara hidup mereka dengan jalan melakukan observasi berperanserta (participant observation). Ia mengajukan teori fungsionalisme, yang berasumsi bahwa semua unsur kebudayaan merupakan bagian-bagian yang berguna bagi masyarakat di mana unsur-unsur tersebut terdapat. Dengan kata lain, pandangan fungsional atas kebudayaan menekankan bahwa setiap pola tingkah-laku, setiap kepercayaan dan sikap yang merupakan bagian dari kebudayaan suatu masyarakat, memerankan fungsi dasar di dalam kebudayaan yang bersangkutan.

Fungsionalisme Struktural; Bebrbagai aspek perilaku sosial bukanlah berkembang untuk memuaskan kebutuhan individual, tapi justru timbul untuk mempertahankan struktur sosial masyarakat. Struktur sosial dari suatu masyarakat adalah seluruh jaringan dan hubungan-hubungan sosial yang ada. Muncul ah sistem kekerabatan dalam suatu kebudayaan.

Permasalahan yang teijadi di aliran ini adalah sulitnya menentukan atau menjelaskan apakah satu kebiasan tertentu pada nyatanya berfungsi dalam arti membantu pemeliharaan sistem sosial masyarakat.

\subsection{Teori Pluralisme (Antropologi Hukum)}

DARI perspektif antropologi hukum, fenomena pluralisme hukum merupakan fakta hukum dalam masyarakat multikultural. John Griffiths (2006) mendefinisikan pluralisme hukum sebagai suatu situasi di mana dua atau lebih sistem hukum bekeija secara berdampingan dalam suatu bidang kehidupan sosial yang sama. 


\section{BAB 3 \\ PENUTUP}

\subsection{Kesimpulan}

Antropologi adalah salah satu cabang ilmu pengetahuan sosial yang mempelajari tentang budaya masyarakat suatu etnis tertentu. Antropologi lahir atau muncul berawal dari ketertarikan orang-orang Eropa yang melihat ciri-ciri fisik, adat istiadat, budaya yang berbeda dari apa yang dikenal di Eropa. Terbentuklah ilmu antropologi dengan melalui beberapa fase. Antropologi lebih memusatkan pada penduduk yang merupakan masyarakat tunggal, tunggal dalam arti kesatuan masyarakat yang tinggal daerah yang sama, antropologi mirip seperti sosiologi tetapi pada sosiologi lebih menitik beratkan pada masyarakat dan kehidupan sosialnya. Perkembangan antropologi terdiri atas 4 tahap yaitu; 1)

\section{Fase Pertama (Sebelum tahun 1800-an)}

Sekitar abad ke-15-16, bangsa-bangsa di Eropa mulai berlomba-lomba untuk menjelajahi dunia. Mulai dari Afrika, Amerika, Asia, hingga ke Australia. Dalam penjelajahannya mereka banyak menemukan hal-hal baru. Mereka juga banyak menjumpai suku-suku yang asing bagi mereka. Kisah-kisah petualangan dan penemuan mereka kemudian mereka catat di buku harian ataupun jumal peijalanan.

Fase Kedua (tahun 1800-an)

Pada fase ini, bahan-bahan etnografi tersebut telah disusun menjadi karangan- karangan berdasarkan cara berpikir evolusi masyarakat pada saat itu. masyarakat dan kebudayaan berevolusi secara perlahan-lahan dan dalam jangka waktu yang lama. Mereka menganggap bangsa-bangsa selain Eropa sebagai bangsa-bangsa primitif yang tertinggal, dan menganggap Eropa sebagai bangsa yang tinggi kebudayaannya Fase Ketiga (awal abad ke-20)

Pada fase ini, negara-negara di Eropa berlomba-lomba membangun koloni di benua lain seperti Asia, Amerika, Australia dan Afrika. Dalam rangka membangun koloni- koloni tersebut, muncul berbagai kendala seperti serangan dari bangsa asli, pemberontakan-pemberontakan, cuaca yang kurang cocok bagi bangsa Eropa serta hambatan-hambatan lain.

Fase Keempat (setelah tahun 1930-an)

Pada fase ini, Antropologi berkembang secara pesat. Kebudayaan-kebudayaan suku bangsa asli yang dijajah bangsa Eropa, mulai hilang akibat terpengaruh kebudayaan bangsa Eropa. 


\subsection{Saran}

Antropologi sangat besar peranannya dalam perkembangan kehidupan manusia sehingga diharapkan kepada kita semua untuk selalu mengembangkan wawasan dan memperdalam pemahaman tentang kehidupan masyarakat yang berkaitan dengan antropologi. 


\section{BAB 4}

\section{DAFTAR PUSTAKA}

Gokma Toni Parlindungan S, Asas Nebis In Idem Dalam Putusan Hakim Dalam Perkara Poligami Di Pengadilan Negeri Pasaman Sebagai Ceriminan Ius Consiiiuium, Volume 2, Nomor 1, 2020.

Gokma Toni Parlindungan S, Pengisian Jabaian Perangkai Nagari Pemekaran Di Pasaman Barai Dalam Rangka Pelaksanaan Oionomi Daerah, Ensiklopedia Of Journal, Vol 1 No 2 Edisi 2 Januari 2019,

Harniwati, Peralihan Hak Ulayat Menurut Undang-Undang Nomor 18 Tahim 2004, Volume 1, Nomor 3, 2019.

Jasmir, Pengembalian Status Hukum Tanah Ulayat Atas Hak Guna Usaha, Soumatera Law Review, Volume 1, Nomor 1, 2018.

Jumrawarsi Jumrawarsi, Neviyarni Suhaili, Peran Seorang Guru Dalam Menciptakan Lingkungan Belajar Yang Kondusif, Ensikopedia Education Review, Vol 2, No 3 (2020): Volume 2 No.3 Desember 2020

Mia Siratni, Proses Perkawinan Menurut Hukum Adatdi Kepulauan Mentawai Di Sebelum Dan Sesudah Berlakunya Undang-Undang Nomor 1 Tahim 1974 Tentang Perkawinan, Ensiklopedia Of Journal, Vol 1 No 2 Edisi 2 Januari 2019,

Remincel, Dimensi Hukum Pelanggaran Kecelakaan Lalu Dan Angkutan Jalan Lintas Di Indonesia, Ensiklopedia Social Review, Volume 1, Nomor 2, 2019.

R Amin, B Nurdin, Konflik Perwakafan Tanah Muhammadiyah di Nagari Singkarak Kabupaten Solok Indonesia 2015-2019, Soumatera Law Review, Volume 3, Nomor 1, 2020 . 